\title{
Analysis of the Pseudomonas putida CA-3 proteome during growth on styrene under nitrogen-limiting and non-limiting conditions
}

Correspondence

Kevin E. O'Connor

kevin.oconnor@ucd.ie

Received 28 May 2009

Revised 8 July 2009

Accepted 9 July 2009

\author{
Jasmina Nikodinovic-Runic, ${ }^{1}$ Michelle Flanagan, ${ }^{2}$ Aisling R. Hume, ${ }^{1}$ \\ Gerard Cagney ${ }^{2}$ and Kevin E. O'Connor ${ }^{1}$
}

${ }^{1}$ School of Biomolecular and Biomedical Science, Centre for Synthesis and Chemical Biology,
University College Dublin, Belfield, Dublin 4, Ireland

${ }^{2}$ Conway Institute, University College Dublin, Belfield, Dublin 4, Ireland

\begin{abstract}
Pseudomonas putida CA-3 is a styrene-degrading bacterium capable of accumulating mediumchain-length polyhydroxyalkanoate (mclPHA) when exposed to limiting concentrations of a nitrogen source in the growth medium. Using shotgun proteomics we analysed global proteome expression in P. putida CA-3 supplied with styrene as the sole carbon and energy source under $\mathrm{N}$-limiting (condition permissive for mcIPHA synthesis) and non-limiting (condition non-permissive for mclPHA accumulation) growth conditions in order to provide insight into the molecular response of $P$. putida CA-3 to limitation of nitrogen when grown on styrene. A total of 1761 proteins were identified with high confidence and the detected proteins could be assigned to functional groups including styrene degradation, energy, nucleotide metabolism, protein synthesis, transport, stress response and motility. Proteins involved in the upper and lower styrene degradation pathway were expressed throughout the $48 \mathrm{~h}$ growth period under both nitrogen limitation and excess. Proteins involved in polyhydroxyalkanoate (PHA) biosynthesis, nitrogen assimilation and amino acid transport, and outer membrane proteins were upregulated under nitrogen limitation. PHA accumulation and biosynthesis were only expressed under nitrogen limitation. Nitrogen assimilation proteins were detected on average at twofold higher amounts under nitrogen limitation. Expression of the branched-chain amino acid $A B C$ transporter was up to 16-fold higher under nitrogen-limiting conditions. Branched chain amino acid uptake by nitrogenlimited cultures was also higher than that by non-limited cultures. Outer membrane lipoproteins were expressed at twofold higher levels under nitrogen limitation. This was confirmed by Western blotting (immunochemical detection) of cells grown under nitrogen limitation. Our study provides the first global description of protein expression changes during growth of any organism on styrene and accumulating mcIPHA (nitrogen-limited growth).
\end{abstract}

\section{INTRODUCTION}

Pseudomonas putida CA-3 has been reported to utilize styrene as a sole source of carbon and energy and to accumulate the biodegradable polymer medium-chainlength polyhydroxyalkanoate (mclPHA) when nitrogen (N) becomes limited in the growth medium (O'Connor et al., 1996; Ward et al., 2005). These two abilities have been employed in the two-step chemo-biotechnological

Abbreviations: CDW, cell dry weight; mclPHA, medium-chain-length polyhydroxyalkanoate; nano-LC MS/MS, nano-electrospray liquid chromatography MS; OMP, outer membrane protein; PA, phenylacetic acid, PHA, polyhydroxyalkanoate; $\mathrm{PHB}$, polyhydroxybutyrate.

Two supplementary tables, listing proteins and peptides identified in the study and spectral count abundance measurements, are available with the online version of this paper. conversion of polystyrene, a non-biodegradable polymer, to mclPHA at laboratory scale (Ward et al., 2006). The process has been improved through the controlled feeding of $\mathrm{N}$ to the growth medium, which results in a twofold increase in biomass and a 1.4-fold increase in mclPHA accumulation (Goff et al., 2007).

Molecular investigations of the styrene degradation pathway in this organism have been reported (Mooney et al., 2006b; O'Connor et al., 2001). Styrene metabolism in $P$. putida CA-3 proceeds via initial side chain oxidation and involves an upper pathway converting styrene to phenylacetic acid (PA) (O'Connor et al., 1995), and a lower pathway initiated via activation of PA to phenylacetyl-CoA. The further metabolism of phenylacetyl-CoA involves oxidation of the aromatic nucleus, followed by ring cleavage and oxidation of the alicyclic compound, 
eventually yielding TCA cycle intermediates (MartinezBlanco et al., 1990; Mooney et al., 2006b; O'Leary et al., 2002b; Olivera et al., 1998). The pha operon in P. putida CA-3 consists of two class II MCL-PHA synthases (phaC1 and phaC2) flanking the PHA depolymerase-encoding phaZ gene (O'Leary et al., 2005).

While traditional metabolic studies have provided information on single or a small number of molecular targets, high-throughput experimental technologies such as proteomics can generate comprehensive datasets that facilitate understanding of the wider metabolic network of the organism (Park \& Lee, 2005). Such system-level analyses are currently changing the strategy of engineering. Bacterial proteome profiling enables elucidation of metabolic networks in bacteria grown under relevant conditions (Krayl et al., 2003; VerBerkmoes et al., 2006). We performed this study with the view to gaining a broader and deeper insight into the response of P. putida CA-3 to N limitation when grown on styrene. We compared the proteome of $P$. putida CA-3 grown on styrene under mclPHA accumulating and non-accumulating conditions, expecting that the broad overviews of the protein expression patterns will facilitate identification of proteins and/or pathways possibly affecting styrene metabolism and PHA accumulation. A number of tests were performed with whole cells and extracts of bacterial cells to confirm certain observations arising from the proteomic data and to quantify those responses biochemically.

\section{METHODS}

P. putida CA-3 growth. P. putida CA-3 (NCIMB 41162) had been isolated previously from a bioreactor containing styrene (O'Connor et al., 1995). Cultures were grown in a 51 stirred tank reactor (Electrolab) with the styrene supplied continuously as a vapour, as described previously (Goff et al., 2007). The growth medium used was minimal mineral salts (MSM) containing, per litre: $9 \mathrm{~g}$ $\mathrm{Na}_{2} \mathrm{HPO}_{4} .12 \mathrm{H}_{2} \mathrm{O}, 1.5 \mathrm{~g} \mathrm{KH}_{2} \mathrm{PO}_{4}, 0.2 \mathrm{~g} \mathrm{MgSO}_{4} .7 \mathrm{H}_{2} \mathrm{O}, 0.002 \mathrm{~g} \mathrm{CaCl}_{2}$ and $1 \mathrm{ml}$ trace element solution (Schlegel et al., 1961). The $\mathrm{N}$ source was $\mathrm{NH}_{4} \mathrm{Cl}$ (Sigma-Aldrich). For mclPHA accumulation, $\mathrm{N}$ was limited with a starting concentration of $65 \mathrm{mg} \mathrm{l}^{-1}$ and a feeding rate of $1.5 \mathrm{mg} \mathrm{l}^{-1} \mathrm{~h}^{-1}$ (Goff et al., 2007). To prevent mclPHA accumulation, $\mathrm{N}$ was supplied at an initial concentration of $525 \mathrm{mg}$ $1^{-1}$ and maintained above $400 \mathrm{mg} \mathrm{l}^{-1}$ using a $\mathrm{N}$ feeding rate of $45 \mathrm{mg}$ $\mathrm{1}^{-1} \mathrm{~h}^{-1}$. Fermentations were performed over a $48 \mathrm{~h}$ period at $30{ }^{\circ} \mathrm{C}$, at an agitation rate of 500 r.p.m. and a controlled pH of 6.8. Samples $(40 \mathrm{ml})$ were taken for analysis at $6,20,30$ and $48 \mathrm{~h}$ (T6, T20, T30 and T48, respectively). From each sample, $10 \mathrm{ml}$ was used for protein preparation, another $10 \mathrm{ml}$ was used for the determination of amino acid uptake rate, and the remainder $(20 \mathrm{ml})$ for mclPHA analysis.

Cell growth was monitored spectrophotometrically $\left(\mathrm{OD}_{540}\right.$; Unicam Helios $\delta$ UV/VIS spectrophotometer) and cell dry weight (CDW) was obtained via a calibration curve of $\mathrm{OD}_{540}$ versus dry weight, where cell suspensions with optical densities ranging from 0.1 to 0.8 were filtered through previously weighed glass fibre membranes (Whatman) and dried at $90{ }^{\circ} \mathrm{C}$ until a constant weight was achieved.

Protein sample preparation. Cells from $10 \mathrm{ml}$ culture aliquots taken from the fermenter at different time points over the $48 \mathrm{~h}$ period of incubation were collected by centrifugation $(5000 \mathrm{~g}$ for $10 \mathrm{~min}$ at
$4{ }^{\circ} \mathrm{C}$ ) and washed twice with an equal volume of phosphate buffer (50 mM, pH 7). Cells were then resuspended in phosphate buffer to an equal concentration of CDW of $1.2 \mathrm{~g}^{-1}$ and centrifuged again. Cell pellets were then resuspended in $500 \mu \mathrm{l}$ BugBuster (primary amine-free, Novagen). Benzonase nuclease (Novagen) and PMSF (Sigma) were added to the suspension at $2 \mathrm{U} \mathrm{ml}^{-1}$ and $0.3 \mathrm{mg} \mathrm{ml}^{-1}$, respectively. Cell suspensions were incubated at $30{ }^{\circ} \mathrm{C}$ with gentle shaking (50 r.p.m.) and the cell debris and unbroken cells removed by centrifugation $\left(5000 \mathrm{~g}\right.$ for $10 \mathrm{~min}$ at $4{ }^{\circ} \mathrm{C}$ ). The protein concentration of the supernatant was determined by the Lowry method using BSA as a standard. Protein samples $(30 \mu \mathrm{l})$ were resuspended in double the volume of $2 \times$ non-reduced SDS-PAGE sample buffer ( $80 \mathrm{mM}$ Tris/ $\mathrm{HCl}, \mathrm{pH} 6.8,10 \% \beta$-mercaptoethanol, $2 \%$ SDS, $10 \%$, v/v, glycerol, $0.1 \%$ Bromophenol Blue) and heated at $100{ }^{\circ} \mathrm{C}$ for $5 \mathrm{~min}$. Denatured proteins were separated on a $10 \%(\mathrm{w} / \mathrm{v})$ polyacrylamide SDS gel and stained with Coomassie Brilliant Blue (Sigma-Aldrich).

Mass spectrometric peptide analysis. SDS-PAGE gels were cut into bands ( 16 bands per time point) and the proteins digested in-gel with trypsin according to the method of Shevchenko et al. (1996). The resulting peptide mixtures were resuspended in $1 \%$ formic acid and analysed by nano-electrospray liquid chromatography MS (nano-LC MS/MS). An HPLC instrument (Dionex) was interfaced with an LTQ ion trap mass spectrometer (ThermoFinnigan). Chromatography buffer solutions (Buffer A, 5\% acetonitrile and $0.1 \%$ formic acid; Buffer B, $80 \%$ acetonitrile and $0.1 \%$ formic acid) were used to deliver a 60 min gradient ( $35 \mathrm{~min}$ to $45 \%$ Buffer B, $10 \mathrm{~min}$ to $90 \%$, hold $10 \mathrm{~min}, 3 \mathrm{~min}$ to $5 \%$, hold for $15 \mathrm{~min}$ ). A flow rate of $2 \mu \mathrm{l} \mathrm{min}$ was used at the electrospray source. Spectra were searched using the Sequest algorithm (Craig \& Beavis, 2004) against the UniProt database restricted to $P$. putida entries (downloaded January 7, 2007). Proteins with (a) a Peptide Prophet probability score greater than 0.99 (Keller et al., 2002), and (b) identified by a minimum of two different peptide spectra were automatically accepted, while spectra for the minority of proteins identified by single spectra were manually checked for quality. Spectral counts were automatically calculated for each protein across different fractions using in-house scripts.

mcIPHA extraction and analysis. Cells collected at different time points of fermentation were harvested by centrifugation $(5000 \mathrm{~g}$ for 10 min at $4{ }^{\circ} \mathrm{C}$ ) and washed twice with an equal volume of phosphate buffer $(50 \mathrm{mM}, \mathrm{pH} 7)$. Cells were centrifuged again (5000 $g$ for $10 \mathrm{~min}$ at $4{ }^{\circ} \mathrm{C}$ ) and freeze-dried. The polymer content was determined by subjecting 5-10 mg lyophilized whole cells to acidic methanolysis according to published protocols (Brandl et al., 1988; Lageveen et al., 1988). This method degrades the intracellular PHA to methyl esters of its constituent 3-hydroxyalkanoic acids. The 3hydroxyalkanoic acid methyl esters were assayed by GC using a Hewlett Packard HP6890 chromatograph equipped with a BP-20 capillary column $(30 \mathrm{~m}$ by $0.25 \mathrm{~mm}, 0.25 \mu \mathrm{m}$ film thickness; J \& W Scientific) and a flame-ionization detector (FID). A temperature programme of $60{ }^{\circ} \mathrm{C}$ for $3 \mathrm{~min}$, temperature ramp of $5{ }^{\circ} \mathrm{C}$ per min, $200{ }^{\circ} \mathrm{C}$ for $1 \mathrm{~min}$ was used. For the peak identification, methyl esters of 3-hydroxyalkanoic acid were prepared in a similar manner and PHA standards from P. putida CA-3 were used (Ward et al., 2005).

Nitrogen assay. The nitrogen concentration in the growth medium was determined by the indophenol method, as described by Scheiner (1976).

Phenylacyl-CoA ligase enzyme assay. The phenylacetyl-CoA ligase activity was determined by measuring the rate of formation of phenylacetylhydroxamate in the presence of cell lysates $(200 \mu \mathrm{l}$; prepared as described in the protein sample preparation section), ATP, CoA, PA and neutral hydroxylamine, as previously described (Martinez-Blanco et al., 1990; Ward \& O’Connor, 2005). Phenylacyl- 
CoA ligase activities were measured at $30{ }^{\circ} \mathrm{C}$ over a 30 min period. The molar extinction coefficient of phenylacetylhydroxamate in the presence of ferric chloride under these conditions is $0.9 \mathrm{mM} \mathrm{cm}$ (Martinez-Blanco et al., 1990; Ward \& O'Connor, 2005).

Branched chain amino acid uptake. For the measurement of leucine and valine uptake rates, $10 \mathrm{ml}$ samples of cells taken from the fermenter at various time points were harvested by centrifugation $\left(5000 \mathrm{~g}\right.$ for $10 \mathrm{~min}$ at $4{ }^{\circ} \mathrm{C}$ ), washed and resuspended in deionized $\mathrm{H}_{2} \mathrm{O}$ to $\mathrm{OD}_{540}$ 4. Cell suspensions $(2 \mathrm{ml})$ were then supplemented with $1 \mathrm{mM}$ leucine and/or $1 \mathrm{mM}$ valine and incubated at $30{ }^{\circ} \mathrm{C}$ with shaking (200 r.p.m.). Samples $(50 \mu \mathrm{l})$ were removed every $30 \mathrm{~min}$ over a $2 \mathrm{~h}$ period. The amino acid detection was based on derivatization with isobutyl chloroformate followed by GC-MS, as described elsewhere (Sobolevsky et al., 2004). Briefly, reaction mixture $(50 \mu \mathrm{l})$ was mixed well with deionized $\mathrm{H}_{2} \mathrm{O}(50 \mu \mathrm{l})$, isobutanol $(30 \mu \mathrm{l})$, pyridine $(10 \mu \mathrm{l})$ and isobutyl chloroformate $(30 \mu \mathrm{l})$. The derivatives were extracted into chloroform $(500 \mu \mathrm{l})$ by vigorous shaking and subsequent centrifugation (10000 $g$ for $1 \mathrm{~min}$ ). A $1 \mu \mathrm{l}$ volume of the chloroform layer was injected in the splitless mode onto an HP-5 column $(20 \mathrm{~m}$ by $0.25 \mathrm{~mm}, 0.33 \mu \mathrm{m}$ film thickness; J \& W Scientific) using an Agilent 6890 gas chromatograph coupled to a 5973 mass-selective detector. The column was held at $50{ }^{\circ} \mathrm{C}$ for $2 \mathrm{~min}$ then heated to $300{ }^{\circ} \mathrm{C}$ at a rate of $10{ }^{\circ} \mathrm{C} \mathrm{min}{ }^{-1}$. Under the above conditions, $\mathrm{N}$-isobutoxycarbonyl isobutyl esters of leucine and valine had retention times of 14.37 and $15.12 \mathrm{~min}$, respectively.

Immunoblotting of outer membrane protein (OMP). Crude cell lysates, prepared as described in Methods, Protein sample preparation, and used for the mass peptide analysis were separated by SDSPAGE $(10 \%, w / v)$ and transferred to a nitrocellulose membrane (Hybond ECL, Amersham Biosciences). For Western blotting, the membrane was probed with mAb 7.3 [mouse antibodies against $P$. putida KT2440 outer membrane lipoprotein as described by RamosGonzalez et al. (1992)]. Peroxidase-conjugated goat anti-mouse immunoglobulins (Merck) were used for the chemiluminescent detection. The blots were developed using Immobilon Western chemiluminescent HRP substrate (Millipore) according to the manufacturer's protocol. Immunoluminescence was detected and evaluated using the chemiluminescence-compatible FluorChem imaging system equipped with AlphaEase FC2 software (Alpha Innotech).

\section{RESULTS AND DISCUSSION}

In order to gain an insight into the effect of $\mathrm{N}$ limitation on the general cellular response, mclPHA accumulation and styrene metabolism, $P$. putida CA-3 was grown in a bioreactor with styrene as the sole source of carbon and energy under two different growth conditions (limited $\mathrm{N}$ and non-limited $\mathrm{N}$ ). The proteomes were profiled over time (T6, T20, T30 and T48) using nano-LC MS/MS (Washburn et al., 2003). This shotgun technique is designed to sample the proteome at a broad level, and uses spectral counts (the frequency with which each protein is detected in the mass spectrometer) as a semiquantitative measure of differential protein expression levels (Cagney et al., 2005). The high-throughput protein annotation and metabolic pathway prediction done in this study were enabled by the availability of the genome sequence of $P$. putida KT2440 (Nelson et al., 2002). The major observations arising from the proteomic analysis were then confirmed by assay and analysis of whole cells, cell extracts and cytoplasmic contents.

\section{Growth characteristics of $\boldsymbol{P}$. putida CA-3}

P. putida CA-3 was grown in the stirred tank bioreactor as previously described (Goff et al., 2007) using styrene as the sole carbon and energy source over $48 \mathrm{~h}$, during which time biomass, $\mathrm{N}$ utilization and PHA production were monitored (Fig. 1). After a $48 \mathrm{~h}$ fermentation, during which the nitrogen (supplied as $\mathrm{NH}_{4} \mathrm{Cl}$ ) concentration was kept above $400 \mathrm{mg} \mathrm{l}^{-1}$, a final biomass of $7.2 \mathrm{~g}^{-1}$ (total $35.8 \mathrm{~g}$ from $5 \mathrm{l}$ culture) was obtained (Fig. 1). No PHA was accumulated under these growth conditions. When the $\mathrm{N}$ supply was limited ( $65 \mathrm{mg} \mathrm{N}^{-1}$ at the start of fermentation), a final CDW of $6.5 \mathrm{~g} \mathrm{l}^{-1}$ was achieved (total $30.3 \mathrm{~g}$ CDW). However, this weight consisted of $52 \%$ PHA $(\mathrm{w} / \mathrm{w}$ ), thus total biomass was $15 \mathrm{~g}$ (a total of $10.2 \mathrm{~g}$ of mclPHA was obtained from $5 \mathrm{l}$ culture). Thus, $\mathrm{N}$ limitation resulted in a 2.4 -fold decrease in biomass yield. During the exponential phase (T6-T25), the growth rates for non-limiting and limiting $\mathrm{N}$ growth conditions were


expected that the different growth rates and concentrations of $\mathrm{N}$ source during fermentation would most likely affect the protein expression pattern (Ferenci, 1999).

\section{Shotgun proteomics of $\boldsymbol{P}$. putida CA-3 grown in a bioreactor on styrene under $\mathbf{N}$ limitation (permissive for PHA accumulation) and under $\mathbf{N}$ excess (not permissive for PHA accumulation)}

P. putida CA-3 cultures were grown as described above and harvested at four time points: $6,20,30$ and $48 \mathrm{~h}$ postinoculation (Fig. 1). In order to produce an extensive dataset of protein expression, the lysate was fractionated by SDS-PAGE and analysed by LC-MS. Over 75000 peptide tandem mass spectra were used to identify 9033 unique peptides, in turn generating 1761 high-confidence $(\geqslant 0.99$ Protein Prophet score) protein identifications (Supplementary Table $\mathrm{S} 1$ ). This represents a substantial proportion (33\%) of the predicted $P$. putida proteome, and reflects the extensive MS analysis at different time points under different growth conditions. Moreover, the proteins exhibited a wide range of annotated biophysical (molecular mass, isoelectric point), biochemical (functional annotations) and structural (domains) properties, suggesting that the analysis was not strongly biased in favour of or against any protein class.

Spectral counts were used as a semiquantitative measure of protein abundance (Cagney et al., 2005; Liu et al., 2004; Washburn et al., 2003). Using this analysis, it was possible to follow the expression of individual proteins in the different samples (Supplementary Table S2, Fig. 2). Comparison of our results with a preliminary experiment using $P$. putida CA-3 cultures suggested that the percentage of proteins detected in two MS analyses of independently 




Fig. 1. Growth (biomass, $\mathrm{g}^{-1}$ ) of $P$. putida $\mathrm{CA}-3$ in minimal salts medium supplied with styrene in the bioreactor under $\mathrm{N}$ -

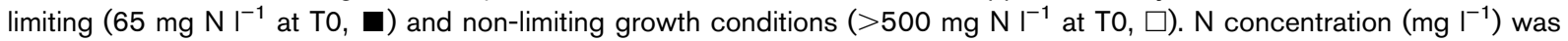
tracked over time under $\mathrm{N}$-limiting $(\boldsymbol{\Delta})$ and non-limiting growth conditions $(\triangle$ ). PHA (as a percentage of CDW) was accumulated under $\mathrm{N}$-limiting conditions only (grey bars). Samples for proteome analysis were taken at $4,20,30$ and $48 \mathrm{~h}$ post-inoculation, as indicated by arrows.

grown cultures is $70-80 \%$ (data not shown). Analysis of 20 ribosomal proteins, whose expression might be assumed to remain relatively independent of the time points and experimental treatment, showed that all 20 were detected in all fractions $(\% \mathrm{CV}$ for spectra counts $=0.34)$. Identified proteins were next organized into functional pathway groups (e.g. 'nitrogen assimilation', 'amino acid uptake') using annotations from the Gene Ontology database (Raghava, 2006). High-throughput protein annotation and metabolic pathway prediction were enabled by the availability of the genome sequence of $P$. putida KT2440 (Nelson et al., 2002). The spectral counts, reflecting the relative abundance of all the proteins engaged in the respective pathways, were then totalled. In this way, potentially up- or downregulated pathways could be observed (Table 1). Changes in the relative abundance of individual proteins or whole pathways are discussed below.

\section{Styrene degradation proteins}

P. putida CA-3 is a styrene-degrading bacterium that metabolizes styrene aerobically, employing enzymes organized in two distinct catabolic pathways (O'Leary et al., 2002b). An upper pathway involves oxidation of the styrene side chain, leading to epoxystyrene, which is subsequently isomerized to phenylacetaldehyde and then oxidized to PA. The lower pathway involves the conversion of the PA through CoA intermediates into aliphatic compounds that can enter the Krebs cycle (Fig. 2a).

The genes encoding the upper pathway are organized on the sty $A B C D$ operon, which is regulated at the transcriptional level by the StySR two-component sensory apparatus in this strain (O'Leary et al., 2001) and other species such as Pseudomonas fluorescens ST (Beltrametti et al., 1997) and Pseudomonas sp. Y2 (Bartolomé-Martin et al., 2004; Velasco et al., 1998). The genes encoding the lower pathway (PACoA catabolon) are typically organized in five contiguous operons: paaABCEF, paaGHIJK, paaLMN, paa $X$ and paaY (Luengo et al., 2001). Proteins encoded by these genes can be classified into functional units: a transport system (PaaL and PaaM); a phenylacetyl-CoAactivating enzyme (PaaF); a ring-hydroxylating enzymic complex (PaaGHIJK); a ring-fission protein (PaaN); a $\beta$ oxidation system (PaaABCE); and two regulatory proteins, a repressor $(\mathrm{PaaX})$ and a putative regulator (PaaY) (Arias et al., 2008; Olivera et al., 1998).

While the typical PACoA catabolon has been suggested to be present in P. putida CA-3 (O'Leary et al., 2005), this is the first time, to our knowledge, that all of the enzymes were detected and their relative amounts observed over time when this strain was grown on styrene (Fig. 2b). All of the enzymes of the upper and lower pathways could be detected throughout the $48 \mathrm{~h}$ fermentation under both 
(a)

UPPER PATHWAY



Styrene

Styrene oxide

Phenylacetaldehyde

Phenylacetic acid

(b)


Fig. 2. Styrene catabolic pathway of $P$. putida CA-3. (a) Styrene upper and lower catabolic pathways, adapted from Nogales et al. (2007) and O'Leary et al. (2002b). (b) Proteins and their relative abundance in cells grown on styrene under no nutrient limitation (white bars) and under $\mathrm{N}$ limitation (grey bars) in the bioreactor. Enzymes and proteins are: StyAB, styrene monooxygenase; StyC, epoxystyrene isomerase; StyD, phenylacetaldehyde dehydrogenase; PaaF, phenylacetyl-CoA ligase; PaaGHIJK, multicomponent phenylacetyl-CoA oxygenase; PaaN and PaaABCDE, enzymes involved in ring-cleavage- and $\beta$ oxidation-like reactions of the aliphatic-CoA intermediates. The consensus nomenclature for the paa genes proposed by Luengo et al. (2001) is used.

$\mathrm{N}$-limiting and non-limiting conditions. However, the relative amounts of the styrene degradation enzymes ranged from $18-22 \%$ under $\mathrm{N}$ excess to $11-18 \%$ under $\mathrm{N}$-limited conditions with respect to the total proteome. StyA and StyD were the most abundant proteins expressed over time in the upper pathway. StyA was expressed to higher levels at time $6 \mathrm{~h}$ under $\mathrm{N}$ limitation but to lower levels after this time point (Fig. 2). This observation is in agreement with our previous finding that the catabolic efficiency of styrene degradation dramatically decreases 
Table 1. Proteins upregulated in $P$. putida CA-3 grown on styrene under $\mathrm{N}$ limitation

\begin{tabular}{|c|c|c|c|c|c|c|c|c|c|}
\hline \multirow[t]{2}{*}{ Functional group and protein name } & \multicolumn{4}{|c|}{$\mathrm{N}$ excess ${ }^{*}$} & \multicolumn{4}{|c|}{ N limitation } & \multirow{2}{*}{$\begin{array}{c}\text { Accession } \\
\text { number } \dagger\end{array}$} \\
\hline & T6 & T20 & T30 & T48 & T6 & T20 & T30 & T48 & \\
\hline \multicolumn{10}{|l|}{ PHA synthesis } \\
\hline Poly(3-hydroxyalkanoate) polymerase 1 & 0 & 0 & 0 & 0 & 0 & 4 & 5 & 8 & Q88D25 \\
\hline Poly(3-hydroxyalkanoate) polymerase 2 & 0 & 0 & 0 & 0 & 0 & 3 & 4 & 14 & Q88D23 \\
\hline Arginine deiminase & 2 & 4 & 4 & 2 & 2 & 14 & 15 & 11 & Q88P52 \\
\hline Nitrogen regulatory protein P-II & 3 & 8 & 4 & 5 & 2 & 3 & 16 & 13 & Q88CE7 \\
\hline Proline iminopeptidase & 0 & 0 & 2 & 1 & 2 & 3 & 10 & 8 & Q88D01 \\
\hline \multicolumn{10}{|l|}{ Transport } \\
\hline $\begin{array}{l}\text { Amino acid } \mathrm{ABC} \text { transporter; periplasmic amino acid } \\
\text { binding protein }\end{array}$ & 2 & 4 & 2 & 3 & 7 & 28 & 16 & 14 & Q88DO5 \\
\hline $\begin{array}{l}\text { Branched chain amino acid } \mathrm{ABC} \text { transporter; periplasmic } \\
\text { amino acid binding protein }\end{array}$ & 1 & 2 & 0 & 0 & 5 & 14 & 18 & 16 & Q88DF8 \\
\hline Membrane efflux protein & 0 & 1 & 1 & 1 & 1 & 2 & 17 & 12 & Q88DA4 \\
\hline \multicolumn{10}{|l|}{ Outer membrane/lipoproteins } \\
\hline Competence lipoprotein ComL; putative & 0 & 0 & 1 & 0 & 1 & 5 & 7 & 8 & Q88Q73 \\
\hline HflC protein & 0 & 0 & 0 & 0 & 1 & 1 & 6 & 4 & Q88DD6 \\
\hline Lipoprotein, putative & 7 & 16 & 21 & 20 & 22 & 29 & 30 & 31 & Q88PU5 \\
\hline Outer membrane lipoprotein OprI & 2 & 3 & 6 & 2 & 2 & 6 & 16 & 11 & Q88KG8 \\
\hline OMP; bacterial surface antigen family & 0 & 2 & 3 & 0 & 2 & 9 & 18 & 19 & Q88MH2 \\
\hline \multicolumn{10}{|l|}{ Stress related } \\
\hline Peroxidase/catalase HPI & 0 & 2 & 1 & 2 & 1 & 13 & 12 & 13 & Q88GQ0 \\
\hline
\end{tabular}

${ }^{\star}$ Numbers refer to spectral counts/peptide score.

$\dagger$ Accession number from UniProtKB/TrEMBL.

under PHA-accumulating (N-limiting) conditions (Ward et al., 2005).

With the exception of PaaE, proteins of the lower pathway were abundant under both N-limiting and non-limiting growth conditions (Fig. 2b). PACoA ligase (PaaF) enzyme activity was detected at similar levels throughout the growth cycle in crude extracts of cells supplied with styrene under $\mathrm{N}$ limitation (Fig. 3). The current observation supports an earlier observation that $\mathrm{N}$ limitation has little effect on the consumption of PA by whole cells grown on styrene (O'Connor et al., 1996). Under full $\mathrm{N}$ growth conditions, extracts of $P$. putida CA-3 cells grown on styrene showed a sharp decrease in both the peptide score for PaaF and PACoA ligase activity at T20 and T48, while the peptide score and enzyme activity at T6 and T30 were higher (Figs 2 and 3). These sharp fluctuations at specific time points raise the possibility that post-translational control of PaaF is occurring.

While Mooney and co-workers demonstrated that StyE, a membrane-associated enzyme, is involved in the facilitated uptake of styrene in P. putida CA-3 (Mooney et al., 2006a), we detected only minor levels of StyE under both $\mathrm{N}$ limiting and non-limiting growth conditions with styrene as the growth substrate (Fig. 2b). These findings suggest that other transporters as well as diffusion play a role in addition to StyE-mediated active transport in the uptake of styrene in P. putida CA-3.

Recently, Nogales and co-workers have established that the final product of aerobic PA degradation in P. putida 


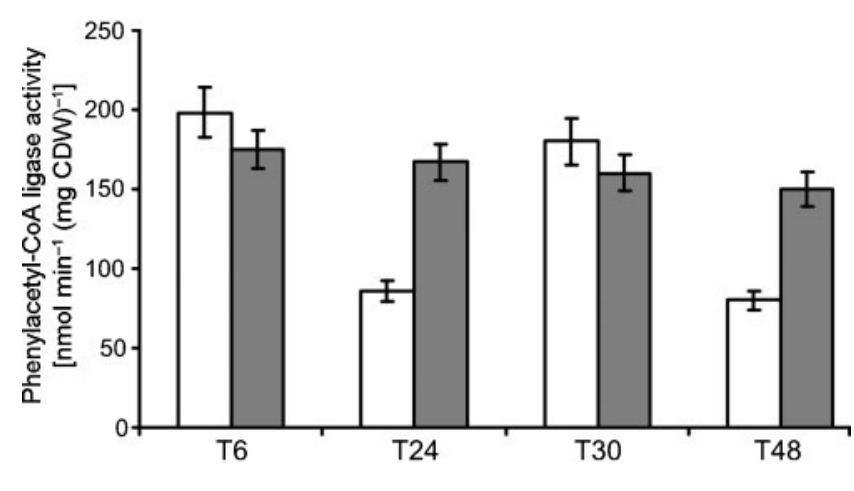

Fig. 3. Phenylacetyl-CoA ligase activities in cell extracts of $P$. putida CA-3 cells grown on styrene (grey bars, $\mathrm{PHA}$-accumulating conditions; white bars, PHA non-accumulating conditions) supplied with PA as substrate $(0.25 \mathrm{mM})$. Data are the average of two independent determinations.

KT2440 is succinyl-CoA (Luengo et al., 2004; Nogales et al., 2007). They also demonstrated, through generation of random insertion mutants and biochemical analysis, that this last step of PA degradation is catalysed by $\beta$ ketoadypil-CoA thiolase (PaaE). PaaE was also detected in $P$. putida CA-3 when grown on styrene under both $\mathrm{N}$ limiting and non-limiting growth conditions (Fig. 2b).

The regulatory proteins StyS, StyR, PaaX and PaaY were detected at low levels, while PA specific permease (PaaL) was not observed in the proteome of $P$. putida CA-3 grown on styrene. O'Leary and co-workers observed that the transcription of the styS gene (upper pathway regulatory sensor kinase) was growth condition-dependent (O'Leary et al., 2002a). Indeed, we observed higher amounts of StyS present under N-limiting conditions (Supplementary Table S1). Del Peso-Santos and co-workers have demonstrated a role for $\mathrm{PaaX}$ as a major regulatory protein in the phenylacetyl-CoA catabolon (del Peso-Santos et al., 2006). They recently revealed that phenylacetyl-CoA binds to $\mathrm{PaaX}$, and inactivates PaaX-mediated repression of both the paa genes and the styABCD operon in P. putida Y2 (del Peso-Santos et al., 2008). In agreement with this, PaaX was the most abundant of the regulators detected at T6 after inoculation under non-limiting $\mathrm{N}$ conditions (data not shown).

\section{Proteins upregulated under $\mathbf{N}$ limitation}

The expression of proteins involved in energy/metabolism, amino acid biosynthesis, DNA/RNA biosynthesis and processing, transcription and translation was quite similar under both $\mathrm{N}$ excess and $\mathrm{N}$ limited conditions (Supplementary Table S1) in P. putida CA-3 over time. Most of the $\mathrm{N}\left(\mathrm{NH}_{4} \mathrm{Cl}\right)$ supplied was consumed within $20 \mathrm{~h}$ of inoculation under $\mathrm{N}$ limitation. Under $\mathrm{N}$ limitation $\left(2 \mathrm{mg} \mathrm{N}^{-1}\right.$ ) the biomass (CDW) yield was $2.4 \mathrm{~g} \mathrm{l}^{-1}$ lower than under $\mathrm{N}$ excess conditions (Fig. 1). The lack of any essential nutrient, including $\mathrm{N}$, causes growth limitation (Ferenci, 1999) and physiological changes, whereby cells attempt to optimize nutrient scavenging and growth. We observed differentially expressed proteins belonging to the pathway groups of $\mathrm{N}$ assimilation, amino acid transport and uptake, outer membrane/lipoproteins, PHA synthesis, motility/chemotaxis and iron assimilation (Fig. 4). Major representative proteins for each of these functional groups with their respective spectral counts are given in Table 1 . In addition, two stress-related proteins (peroxidase/catalase HPI and ATP-dependent Clp protease) were observed to be slightly upregulated under $\mathrm{N}$ limitation (Table 1).

\section{Upregulation of $\mathbf{N}$ assimilation}

As expected, one of the most strongly affected functional groups under $\mathrm{N}$-limited growth were the nitrogen assimilation proteins (Fig. 4). This group is represented by arginine deiminase, $\mathrm{N}$ regulatory protein $\mathrm{P}-\mathrm{II}$ and proline iminopeptidase (Table 1), but also contains proteins such as $\mathrm{N}$ utilization substance protein $\mathrm{A}$, nitrate binding protein NasS, nitrite reductase, nitroreductase and aminotransferases. $\mathrm{N}$ assimilation proteins represented $8 \%$ of total detected proteins at $30 \mathrm{~h}$ of fermentation, while at the same time point of fermentation when $\mathrm{N}$ was supplied in excess $4.4 \%$ of total proteins detected were associated with $\mathrm{N}$ assimilation. Arginine deiminase (EC 3.5.3.6) together with proline deaminase (EC 3.4.11.5) was the most abundant protein in this group. Arginine deaminase from Pseudomonas aeruginosa (PaADI) catalyses the hydrolysis of arginine to citrulline and ammonium ion, which is the first step of the microbial L-arginine degradation pathway (Lu et al., 2006). Proline iminopeptidase is also a hydrolytic enzyme involved in proteolysis as one of the ways to assimilate $\mathrm{N}$ when its supply is limited.

In poor growth conditions, the metabolism of cells is oriented towards an economical use of substrates by utilization of the available metabolites for the synthesis of

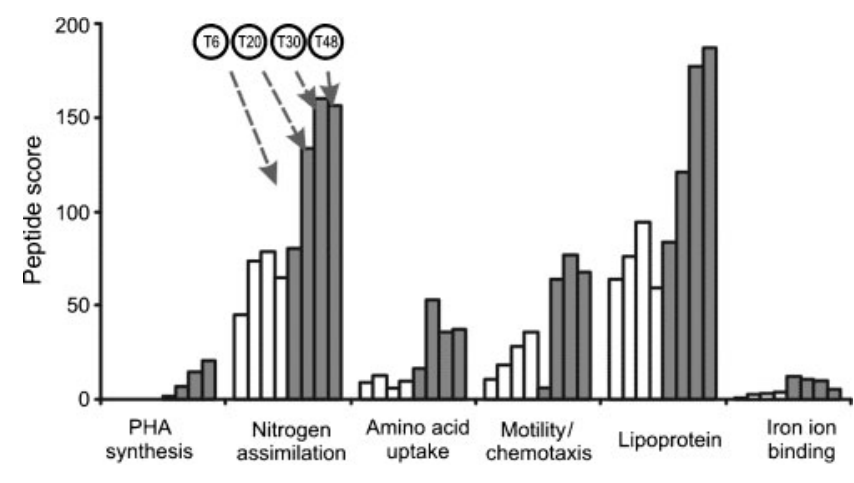

Fig. 4. Protein groups of $P$. putida $C A-3$ upregulated during growth on styrene under $\mathrm{N}$-limiting conditions (grey bars, PHAaccumulating conditions) with respect to no nutrient limitation conditions (white bars, PHA non-accumulating conditions). 
proteins and nucleic acids (Lavallee et al., 2005). Here, we observed increased levels of amino acid transport proteins under N-limiting conditions (Table 1). This was confirmed in branched chain amino acid uptake experiments, where samples taken from the bioreactor at T48 grown under $\mathrm{N}$ limiting conditions showed 2.2-fold higher leucine uptake compared with cells cultured under non-limiting growth conditions (Fig. 5). All bacterial cell samples were normalized so that they had the same biomass ( $\mathrm{g}$ $\mathrm{CDW}^{-1}$ ) in the amino acid uptake assay. Cells harvested from the $\mathrm{N}$-limited fermentation at T48 consumed 1.5-fold more leucine than cells harvested at T6 over the $2 \mathrm{~h}$ test period (Fig. 5). In all samples tested $\mathrm{N}$ limited cells had a higher rate of leucine uptake than cells grown under nonlimiting conditions (Fig. 5). Similar results were obtained when the amino acid used was valine (data not shown). These data were in agreement with the amounts of branched chain amino acid transporters detected by MS analysis (Table 1).



Fig. 5. Branched chain amino acid (leucine) uptake rate of $P$. putida CA-3 cells grown on styrene in a bioreactor under $\mathrm{N}$ nonlimiting conditions (a, open symbols) and $\mathrm{N}$-limiting conditions (b, filled symbols). Samples were taken at $6 \mathrm{~h}$ (diamonds), $24 \mathrm{~h}$ (circles), $30 \mathrm{~h}$ (triangles) and $48 \mathrm{~h}$ (squares) from the bioreactor. Data are an average from two independent determinations.
Proteins involved in polyamine (putrescine) metabolism were also upregulated under $\mathrm{N}$-limiting growth conditions (Supplementary Table S1). Polyamines (including putrescine and spermidine) are a group of ubiquitous polycations necessary for cell growth (Lu et al., 2002). In P. aeruginosa, putrescine can be synthesized from arginine through the arginine decarboxylase pathway (Patel et al., 2006). Through this pathway, arginine is sequentially converted and channelled into the tricarboxylic acid cycle (Patel et al., 2006). In cells grown under $\mathrm{N}$ limitation, the polyamine $\mathrm{ABC}$ transporters were particularly abundant, reflecting the cellular mechanisms used to deal with the $\mathrm{N}$ limitation. Other transport proteins were also upregulated, providing a range of means for scavenging N-based compounds. Santos et al. (2004) suggested that the differential expression of $\mathrm{ABC}$ transporters serves as a global signal for response to the concentration and the quality of the carbon source, starvation conditions and toxic stress. $\mathrm{N}$ limitation also stimulated upregulation of the proteolytic enzymes (Hsl protease, ATP-dependent La protease and SohB).

\section{mcIPHA synthesis occurs only under $\mathbf{N}$ limitation}

One of the metabolic adaptations to suboptimal $\mathrm{N}$ levels during $P$. putida CA-3 growth on styrene is the accumulation of an intracellular carbon and energy storage material in the form of mclPHA granules (Ward et al., 2006). This has also been observed in many other micro-organisms as a response to stress imposed on cells during imbalanced growth, when essential nutrients are limited and carbon is in abundance (Hoffmann \& Rehm, 2005; Rehm, 2007; Wältermann \& Steinbüchel, 2005).

PHA accumulation was observed under $\mathrm{N}$-limiting growth conditions when the $\mathrm{N}$ levels reached a concentration of $26 \mathrm{mg} \mathrm{l}^{-1}$ (T6). PHA accumulation continued throughout the fermentation, during which time $\mathrm{N}$ was kept at low levels $\left(2-3 \mathrm{mg} \mathrm{l}^{-1}\right.$ ) using a feeding strategy described by Goff et al. (2007). PHA levels increased 12 -fold over $14 \mathrm{~h}$ (from T6 to T20), with a further 1.5- and 2.2-fold increase over the following 10 and $28 \mathrm{~h}$, respectively (Fig. 1). No PHA was detected in cells grown with $\mathrm{N}$ excess.

PHA biosynthetic proteins were detected in the proteome of $P$. putida CA-3 cells grown under $\mathrm{N}$ limitation (Fig. 4). We observed poly(3-hydroxyalkanoate) polymerase 1 (PhaC1), poly(3-hydroxyalkanoate) polymerase 2 (PhaC2), 3-hydroxyacyl-CoA-acyl carrier protein transferase (PhaG), and granule-associated proteins 1 and 2 (Table 1). The PHA biosynthetic enzymes were detected at relatively low levels, while the depolymerase was not detected in proteomes of $P$. putida CA-3 during the course of this study. It has been documented that in PHAproducing organisms the polymerase and depolymerase, as well as phasin enzymes, are associated with PHA granules and form a distinct protein surface network (Pötter et al., 2004; Pötter \& Steinbüchel, 2005; Sandoval et al., 2007). PHA granules are synthesized by PHA polymerases that 
utilize CoA thioesters of the respective 3-hydroxy fatty acids as substrates. Granules are mobilized (degraded) by PHA depolymerases, and formation of the granules depends on the activity of several granule-associated proteins (phasins).

\section{Lipoproteins, chemotaxis-related proteins and iron ion transport proteins are upregulated under N limitation}

In cells accumulating PHA (grown under N-limiting conditions) we observed upregulation of other OMPs, such as lipoproteins and lipoprotein-releasing proteins (Lol proteins), that target and anchor lipoproteins to the periplasmic surface of either the inner or the outer membrane (Miyamoto \& Tokuda, 2007; Narita \& Tokuda, 2006). It has been shown that nutrient limitation induces the expression of proteins in the outer membrane of bacterial cells such as Pseudomonas species under carbon, $\mathrm{N}$ and phosphorus limitation (Kragelund \& Nybroe, 1994). Lipoproteins have been shown to have emulsifying properties that increase surface area and hence enhance the bioavailability of hydrophobic substrates such as styrene (Kuiper et al., 2004; Whang et al., 2008). They are also known to play a role in the bacterial adaptation to changes in environmental conditions such as osmotic stress (Guyard-Nicodème et al., 2008). Among OMPs, OmpA, G, $\mathrm{H}, \mathrm{E} 3, \mathrm{~F}$ and I were detected in the current study, but only OmpF and OmpA porins were twofold to fourfold upregulated by $\mathrm{N}$ limitation (Table 1, Supplementary Table S1). OmpF is a major membrane protein in $P$. aeruginosa, where it has a non-specific porin function (Hancock \& Brinkman, 2002). In fact, Li et al. (1995) have demonstrated that an ompF mutant of $P$. aeruginosa was toluene-tolerant, and therefore it was proposed that toluene enters the cell through the OmpF channel in wild-type cells. In contrast, Volkers and co-workers found that $\mathrm{OmpF}$ is downregulated in the presence of toluene excess in a chemostat-based culture of P. putida S12 and proposed that this strain is capable of shutting down this channel upon toluene stress (Volkers et al., 2006). In the same study, OmpH was dramatically upregulated (12fold), while we observed more moderate (twofold) upregulation of this OMP. The higher levels of OmpA observed in this study are in agreement with the findings of Benndorf and co-workers, who identified OmpA as being upregulated in P. putida KT2440 in response to lipophilic herbicides (Benndorf et al., 2006).

Proteomic data were confirmed through Western blotting using a highly specific monoclonal antibody (mAb 7.3) which was previously raised against surface determinants of P. putida 2440 (LPS and membrane proteins) (RamosGonzalez et al., 1992). Approximately 1.7-fold higher amounts of outer membrane lipoproteins containing Oantigen were detected in cells grown under $\mathrm{N}$ limitation compared with cells grown under $\mathrm{N}$ excess at $\mathrm{T} 48$, as determined by densitometry (Fig. 6). Interestingly, two

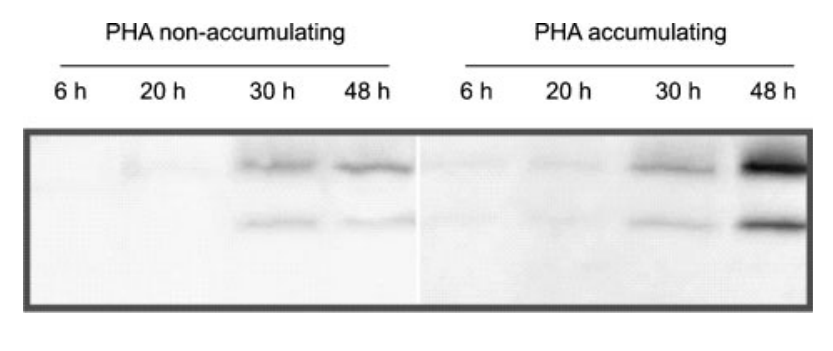

Fig. 6. Outer membrane lipoproteins with $\mathrm{O}$-antigen from styrenegrown $P$. putida CA-3 cells grown in a bioreactor. A $30 \mu$ quantity of the whole-cell lysate from each sample was resolved by SDSPAGE (10\%), immunoblotted and probed with mAb 7.3 antibodies (Ramos-Gonzalez et al., 1992).

bands were observed when mAb 7.3 was used. This suggests that P. putida CA-3 has more than one unit of $\mathrm{O}$-antigen in its LPS (Fig. 6). Cowell et al. (1999) suggested that the increased adhesion to surfaces exhibited by $P$. aeruginosa grown under $\mathrm{N}$ limitation is due to an increase in OMP expression.

Under N-limiting (PHA accumulation) conditions, a number of motility-associated proteins were upregulated (Fig. 4, Table 1$)$. The majority of these proteins $(\sim 80 \%)$ were chemotaxis-related proteins, including chemotaxis histidine kinase CheA, chemotaxis proteins $\mathrm{CheV}, \mathrm{Y}$ and $\mathrm{Z}$, and a variety of methyl-accepting chemotaxis transducers. These methyl-accepting chemotaxis transducers are outer membrane receptors that mediate chemotaxis to diverse signals, responding to changes in the concentration of attractants and repellents in the environment by changing swimming behaviour (Adler, 1966). This has been observed in $P$. putida in response to various substances, including naphthalene (Grimm \& Harwood, 1997; Harwood et al., 1990; Law \& Aitken, 2006). The second group of motilityrelated proteins that was upregulated were flagellar biosynthetic proteins such as FliA, C, F, E, G, K and N. The importance of chemotaxis and flagellins was identified in a study by Raberg and co-workers, who studied flagellation changes in response to nutrient supply and the state of polyhydroxybutyrate ( $\mathrm{PHB}$ ) production in Ralstonia eutropha H16 (Raberg et al., 2008).

We have also identified number of proteins involved in iron ion acquisition and storage that were induced by $\mathrm{N}$ limiting growth conditions (Fig. 4, Table 1). The most differentially expressed was bacterioferritin (Q88NX1), a protein that interacts with siderophores. Ferritins are part of a class of iron binding proteins that reversibly sequester excess iron and can thereby serve to ease iron-related oxidative stress (Smith, 2004). Bacterioferritins whose expression levels vary as a function of environmental and intracellular iron levels have been identified in P. putida KT2440 (Chen et al., 2009). Similarly, bacterioferritins are highly expressed in biofilms of $P$. aeruginosa (Patrauchan et al., 2007), but they have not been identified as being upregulated under $\mathrm{N}$-limited growth conditions. 


\section{Solvent tolerance response by P. putida CA-3 to the presence of styrene}

When grown on styrene, $P$. putida CA-3 cells face a paradox. On the one hand, styrene represents a carbon source that can be metabolized to yield carbon and energy for growth. On the other hand, with an octanol/water partition coefficient $\left[\log \left(\mathrm{P}_{\mathrm{OW}}\right)\right]$ of 3 , styrene falls into a category of organic solvents extremely toxic to microorganisms, due to their ability to bind to the cells, disturbing membranes by removing lipids and proteins and causing cell lysis (Ramos et al., 2001; Taylor et al., 2008). It is well documented that solvent-tolerant pseudomonads possess three membrane-associated solvent tolerance mechanisms: (A) active efflux of organic solvents, (B) outer membrane changes and (C) cytoplasmic membrane changes (Volkers et al., 2006).

(A) Active efflux of organic solvents. Several laboratories have identified efflux pumps belonging to the resistancenodulation-cell division (RND) family as being the most important mechanism of solvent tolerance (Kieboom et al., 1998; Ramos et al., 2001). They are energy-dependent active efflux pumps, which export toxic organic solvents to the external medium. This mechanism has also been identified in P. putida KT2440 (Benndorf et al., 2006). These efflux pumps were present throughout the fermentation of $P$. putida CA-3 under both N-limiting and $\mathrm{N}$-excess growth conditions. (e.g. UniProtKB/TrEMBL Q88DA4, homologous to toluene efflux pump). Nevertheless, these proteins were present at considerably higher levels (by a factor of 10) by T30 under N-limiting conditions (Table 1). It has been determined elsewhere that the operation of these efflux pumps seems to be coupled to the proton motive force, that they have dual pumping capacity, and that specific and global regulators control their expression at the transcriptional level (Kieboom et al., 1998; Ramos et al., 2002).

(B) Outer membrane changes. An integral part of the efflux systems described above are OMPs, which represent an outer membrane channel by which the pumped molecule is released into the medium (Kieboom \& De Bont, 2001). OMPs associated with the efflux pumps (TolC, OmpJ) were detected in the proteome of $P$. putida CA-3 grown on styrene (Supplementary Table S1). As described above in Results and Discussion, Lipoproteins, chemotaxis-related proteins and iron ion transport proteins upregulated under $\mathrm{N}$ limitation, a putative lipoprotein is expressed by cells grown on styrene, but increased outer membrane lipoprotein and bacterial surface antigen expression occurs under $\mathrm{N}$ limitation.

(C) Cytoplasmic membrane changes. An immediate response of micro-organisms to harsh environmental conditions (chemical or physical stresses) is the readjustment of cell-membrane fluidity by the alteration of their phospholipid composition. One of the key elements in this response is the cis to trans isomerization of unsaturated fatty acids by the Cti isomerase, which causes membrane rigidity (Heipieper et al., 1996; von Wallbrunn et al., 2003). However, in this study, Cti isomerase (which is located in the periplasm) was not detected. In agreement with this finding, Junker and coworkers described a $P$. putida DOT-T1E Cti null mutant that is still able to survive at high toluene concentrations, indicating that although important, cis/trans isomerization is not essential for bacterial solvent resistance (Junker \& Ramos, 1999).

Given that the Cti fatty acid isomerase was not detected in this study, it would appear that efflux pumps and outer membrane lipoproteins (i.e. Q88MH2, Table 1) are more likely to be involved in the maintenance and integrity of the cell membrane in P. putida CA-3 grown on styrene, especially under $\mathrm{N}$-limiting conditions.

\section{Stress-related proteins}

A number of proteins involved in detoxification, oxidative stress response and protein folding mechanisms were identified with higher spectral counts in cells grown under $\mathrm{N}$ limitation, e.g. peroxidase/catalase HPI and ATPdependent Clp protease (Table 1). It is thought that the catalase/peroxidase subfamily provides protection under oxidative stress in bacteria (Welinder, 1991). Increased catalase levels have been detected in the proteome of Pseudomonas sp. M1 and KT2440 when grown on or in the presence of phenol (Santos et al., 2004, 2007). Multiple stress-related proteins, such as AphC, SodB and other antioxidants, are induced in P. putida KT2440 cells in the presence of a range of aromatic substrates (Kim et al., 2006). The presence of stress-related proteins in cells grown on styrene supports the claim that styrene has a toxic effect on bacteria cells (Ramos et al., 2001). Bacteria accumulating PHB have been previously reported to upregulate heat shock (HspA) proteins in response to stress (Kang et al., 2008; Tessmer et al., 2007). The authors propose that HspA can act like a PHA granule-associated protein (phasin) which affects PHA granule coalescence (Tessmer et al., 2007). In the current study, Clp protease (subunit ClpX) was upregulated in P. putida CA-3 cells under $\mathrm{N}$ limitation (Table 1). Recently, we generated a transposon mutant negatively affected in PHA accumulation disrupted in the clpA gene, suggesting that the activity of the ClpP protease is important for PHA accumulation in P. putida CA-3 (Goff et al., 2009). While some members of the Clp family are involved in proteolysis regulation, this family also has many attributes of molecular chaperones (Squires \& Squires, 1992). ClpXP is involved in DNA damage repair, stationary-phase gene expression and protein quality control (Neuwald et al., 1999), and to date more than 50 proteins, including transcription factors, metabolic enzymes, and proteins involved in the starvation and oxidative stress responses, have been identified as substrates (Flynn et al., 2003). Clp protease in Bacillus subtilis 
$\mathrm{ClpP}$ is thought to play a role during heat shock as well as oxidative and salt stress (Volker et al., 1994), while in $P$. fluorescens (O'Toole \& Kolter, 1998), it is linked to biofilm formation, which is a bacterial response to specific environmental triggers/stresses.

\section{Conclusions}

A wide variety of proteins are expressed in P. putida CA-3 in response to the presence of styrene and limiting concentrations of $\mathrm{N}$ in the growth medium. The broad range of these proteins indicates the complex and varied response of this bacterium to the presence of a lipophilic substrate (styrene) and to the decrease in the concentration of an essential inorganic nutrient $(\mathrm{N})$. The internal and surface protein expression response also reveals the multifaceted nature of the physiological response of $P$. putida CA-3 to environmental stimuli. The data generated here will allow us to investigate specific molecular targets to examine the effect of gene disruption on styrene metabolism, $\mathrm{N}$ assimilation and mclPHA accumulation by $P$. putida CA-3. The data also form a basis for the design and evaluation of future metabolic engineering efforts, where analysis of multiple pathways and global responses will increase as this field moves towards systems biology methods (Park et al., 2008).

\section{ACKNOWLEDGEMENTS}

We thank Dr Juan L. Ramos and Dr Maribel Ramos (CSIC, Estacion Experimental del Zaidin, Granada, Spain) for providing mAb 7.3 monoclonal antibodies. This project has been funded under a grant from the Environmental Protection Agency of Ireland (ERTDI 2005ET-LS-9-M3).

\section{REFERENCES}

Adler, J. (1966). Chemotaxis in bacteria. Science 153, 708-715.

Arias, S., Olivera, E. R., Arcos, M., Naharro, G. \& Luengo, J. M. (2008). Genetic analyses and molecular characterization of the pathways involved in the conversion of 2-phenylethylamine and 2-phenylethanol into phenylacetic acid in Pseudomonas putida U. Environ Microbiol 10, 413-432.

Bartolomé-Martin, D., Martinez-Garcia, E., Mascaraque, V., Rubio, J., Perera, J. \& Alonso, S. (2004). Characterization of a second functional gene cluster for the catabolism of phenylacetic acid in Pseudomonas sp. strain Y2. Gene 341, 167-179.

Beltrametti, F., Marconi, A. M., Bestetti, G., Colombo, C., Galli, E., Ruzzi, M. \& Zennaro, E. (1997). Sequencing and functional analysis of styrene catabolism genes from Pseudomonas fluorescens ST. Appl Environ Microbiol 63, 2232-2239.

Benndorf, D., Thiersch, M., Loffhagen, N., Kunath, C. \& Harms, H. (2006). Pseudomonas putida KT2440 responds specifically to chlorophenoxy herbicides and their initial metabolites. Proteomics 6, 33193329.

Brandl, H., Gross, R. A., Lenz, R. W. \& Fuller, R. C. (1988). Pseudomonas oleovorans as a source of poly( $\beta$-hydroxyalkanoates) for potential applications as biodegradable polyesters. Appl Environ Microbiol 54, 1977-1982.
Cagney, G., Park, S., Chung, C., Tong, B., O’Dushlaine, C., Shields, D. C. \& Emili, A. (2005). Human tissue profiling with multidimensional protein identification technology. J Proteome Res 4, 1757-1767.

Chen, S., Bleam, W. F. \& Hickey, W. J. (2009). Simultaneous analysis of bacterioferritin gene expression and intracellular iron status in Pseudomonas putida KT2440 by using a rapid dual luciferase reporter assay. Appl Environ Microbiol 75, 866-868.

Cowell, B. A., Willcox, M. D. P., Herbert, B. \& Schneider, R. P. (1999). Effect of nutrient limitation on adhesion characteristics of Pseudomonas aeruginosa. J Appl Microbiol 86, 944-954.

Craig, R. \& Beavis, R. C. (2004). TANDEM: matching proteins with tandem mass spectra. Bioinformatics 20, 1466-1467.

del Peso-Santos, T., Bartolomé-Martin, D., Fernandez, C., Alonso, S., Garcia, J. L., Diaz, E., Shingler, V. \& Perera, J. (2006). Coregulation by phenylacetyl-coenzyme A-responsive PaaX integrates control of the upper and lower pathways for catabolism of styrene by Pseudomonas sp. strain Y2. J Bacteriol 188, 4812-4821.

del Peso-Santos, T., Shingler, V. \& Perera, J. (2008). The styreneresponsive StyS/StyR regulation system controls expression of an auxiliary phenylacetyl-coenzyme A ligase: implications for rapid metabolic coupling of the styrene upper- and lower-degradative pathways. Mol Microbiol 69, 317-330.

Ferenci, T. (1999). Regulation by nutrient limitation. Curr Opin Microbiol 2, 208-213.

Flynn, J. M., Neher, S. B., Kim, Y. I., Sauer, R. T. \& Baker, T. A. (2003). Proteomic discovery of cellular substrates of the ClpXP protease reveals five classes of ClpX-recognition signals. Mol Cell 11, 671-683.

Goff, M., Ward, P. G. \& O'Connor, K. E. (2007). Improvement of the conversion of polystyrene to polyhydroxyalkanoate through the manipulation of the microbial aspect of the process: a nitrogen feeding strategy for bacterial cells in a stirred tank reactor. J Biotechnol 132, 283-286.

Goff, M., Nikodinovic-Runic, J. \& O'Connor, K. (2009). Characterisation of temperature sensitive and lipopolysaccharide overproducing transposon mutants of Pseudomonas putida CA-3 affected in PHA accumulation. FEMS Microbiol Lett 292, 297-305.

Grimm, A. C. \& Harwood, C. S. (1997). Chemotaxis of Pseudomonas spp. to the polyaromatic hydrocarbon naphthalene. Appl Environ Microbiol 63, 4111-4115.

Guyard-Nicodème, M., Bazire, A., Hemery, G., Meylheuc, T., Mollé, D., Orange, N., Fito-Boncompte, L., Feuilloley, M., Haras, D. \& other authors (2008). Outer membrane modifications of Pseudomonas fluorescens MF37 in response to hyperosmolarity. J Proteome Res 7, 1218-1225.

Hancock, R. E. \& Brinkman, F. S. (2002). Function of Pseudomonas porins in uptake and efflux. Annu Rev Microbiol 56, 17-38.

Harwood, C. S., Parales, R. E. \& Dispensa, M. (1990). Chemotaxis of Pseudomonas putida toward chlorinated benzoates. Appl Environ Microbiol 56, 1501-1503.

Heipieper, H. J., Meulenbeld, G., van Oirschot, Q. \& de Bont, J. A. M. (1996). Effect of environmental factors on the trans/cis ratio of unsaturated fatty acids in Pseudomonas putida S12. Appl Environ Microbiol 62, 2773-2777.

Hoffmann, N. \& Rehm, B. H. A. (2005). Nitrogen-dependent regulation of medium-chain length polyhydroxyalkanoate biosynthesis genes in pseudomonads. Biotechnol Lett 27, 279-282.

Junker, F. \& Ramos, J. L. (1999). Involvement of the cis/trans isomerase Cti in solvent resistance of Pseudomonas putida DOT-T1E. J Bacteriol 181, 5693-5700. 
Kang, Z., Wang, Q., Zhang, H. \& Qi, Q. (2008). Construction of a stress-induced system in Escherichia coli for efficient polyhydroxyalkanoates production. Appl Microbiol Biotechnol 79, 203-208.

Keller, A., Nesvizhskii, A. I., Kolker, E. \& Aebersold, R. (2002). Empirical statistical model to estimate the accuracy of peptide identifications made by MS/MS and database search. Anal Chem 74, 5383-5392.

Kieboom, J. \& De Bont, J. A. M. (2001). Identification and molecular characterization of an efflux system involved in Pseudomonas putida S12 multidrug resistance. Microbiology 147, 43-51.

Kieboom, J., Dennis, J. J., Zylstra, G. J. \& De Bont, J. A. M. (1998). Active efflux of organic solvents by Pseudomonas putida $\mathrm{S} 12$ is induced by solvents. J Bacteriol 180, 6769-6772.

Kim, Y. H., Cho, K., Yun, S.-H., Kim, J. Y., Kwon, K.-H., Yoo, J. S. \& Kim, S. I. (2006). Analysis of aromatic catabolic pathways in Pseudomonas putida KT 2440 using a combined proteomic approach: 2-DE/MS and cleavable isotope-coded affinity tag analysis. Proteomics 6, 1301-1318.

Kragelund, L. \& Nybroe, O. (1994). Culturability and expression of outer membrane proteins during carbon, nitrogen, or phosphorus starvation of Pseudomonas fluorescens DF57 and Pseudomonas putida DF14. Appl Environ Microbiol 60, 2944-2948.

Krayl, M., Benndorf, D., Loffhagen, N. \& Babel, W. (2003). Use of proteomics and physiological characteristics to elucidate ecotoxic effects of methyl tert-butyl ether in Pseudomonas putida KT2440. Proteomics 3, 1544-1552.

Kuiper, I., Lagendijk, E. L., Pickford, R., Derrick, J. P., Lamers, G. E. M., Thomas-Oates, J. E., Lugtenberg, B. J. J. \& Bloemberg, G. V. (2004). Characterization of two Pseudomonas putida lipopeptide biosurfactants, putisolvin I and II, which inhibit biofilm formation and break down existing biofilms. Mol Microbiol 51, 97-113.

Lageveen, R. G., Huisman, G. W., Preusting, H., Ketelaar, P., Eggink, G. \& Witholt, B. (1988). Formation of polyesters by Pseudomonas oleovorans: effect of substrates on formation and composition of poly- $(R)$-3-hydroxyalkanoates and poly-( $R)$-3-hydroxyalkenoates. Appl Environ Microbiol 54, 2924-2932.

Lavallee, B., Lessard, P. \& Vanrolleghem, P. A. (2005). Review of procaryote metabolism in view of modeling microbial adaptation from fast growth to starvation conditions. J Environ Eng Sci 4, 517532.

Law, A. M. J. \& Aitken, M. D. (2006). The effect of oxygen on chemotaxis to naphthalene by Pseudomonas putida G7. Biotechnol Bioeng 93, 457-464.

Li, L., Komatsu, T., Inoue, A. \& Horikoshi, K. (1995). A toluenetolerant mutant of Pseudomonas aeruginosa lacking the outer membrane protein F. Biosci Biotechnol Biochem 59, 2358-2359.

Liu, H., Sadygov, R. G. \& Yates, J. R. I. (2004). A model for random sampling and estimation of relative protein abundance in shotgun proteomics. Anal Chem 76, 4193-4201.

Lu, C.-D., Itoh, Y., Nakada, Y. \& Jiang, Y. (2002). Functional analysis and regulation of the divergent spuABCDEFGH-spuI operons for polyamine uptake and utilization in Pseudomonas aeruginosa PAO1. J Bacteriol 184, 3765-3773.

Lu, X., Li, L., Wu, R., Feng, X., Li, Z., Yang, H., Wang, C., Guo, H., Galkin, A. \& other authors (2006). Kinetic analysis of Pseudomonas aeruginosa arginine deiminase mutants and alternate substrates provides insight into structural determinants of function. Biochemistry 45, 1162-1172.

Luengo, J. M., Garcia, J. L. \& Olivera, E. R. (2001). The phenylacetylCoA catabolon: a complex catabolic unit with broad biotechnological applications. Mol Microbiol 39, 1434-1442.
Luengo, J. M., Arias, S., Sandoval, A., Arias-Barrau, E., Arcos, M., Naharro, G. \& Olivera, E. R. (2004). From aromatics to bioplastics: the phenylacetyl-CoA catabolon as a model of catabolic convergence. Rec Res Dev Bioph Biochem 4, 257-292.

Martinez-Blanco, H., Reglero, A., Rodriguez-Aparicio, L. B. \& Luengo, J. M. (1990). Purification and biochemical characterization of phenylacetyl-CoA ligase from Pseudomonas putida: a specific enzyme for the catabolism of phenylacetic acid. J Biol Chem 265, 7084-7090.

Miyamoto, S. \& Tokuda, H. (2007). Diverse effects of phospholipids on lipoprotein sorting and ATP hydrolysis by the ABC transporter LolCDE complex. Biochim Biophys Acta 1768, 1848-1854.

Mooney, A., O'Leary, N. D. \& Dobson, A. D. (2006a). Cloning and functional characterization of the $s t y E$ gene, involved in styrene transport in Pseudomonas putida CA-3. Appl Environ Microbiol 72, 1302-1309.

Mooney, A., Ward, P. G. \& O'Connor, K. (2006b). Microbial degradation of styrene: biochemistry, molecular genetics, and perspectives for biotechnological applications. Appl Microbiol Biotechnol 72, 1-10.

Narita, S.-i. \& Tokuda, H. (2006). An ABC transporter mediating the membrane detachment of bacterial lipoproteins depending on their sorting signals. FEBS Lett 580, 1164-1170.

Nelson, K. E., Weinel, C., Paulsen, I. T., Dodson, R. J., Hilbert, H., Martins dos Santos, V. A., Fouts, D. E., Gill, S. R., Pop, M. \& other authors (2002). Complete genome sequence and comparative analysis of the metabolically versatile Pseudomonas putida KT2440. Environ Microbiol 4, 799-808.

Neuwald, A. F., Aravind, L., Spouge, J. L. \& Koonin, E. V. (1999). A class of chaperone-like ATPases associated with the assembly, operation, and disassembly of protein complexes. Genome Res $\mathbf{9}$, 27-43.

Nogales, J., Macchi, R., Franchi, F., Barzaghi, D., Fernandez, C., Garcia, J. L., Bertoni, G. \& Díaz, E. (2007). Characterization of the last step of the aerobic phenylacetic acid degradation pathway. Microbiology 153, 357-365.

O’Connor, K., Buckley, C. M., Hartmans, S. \& Dobson, A. D. W. (1995). Possible regulatory role for nonaromatic carbon sources in styrene degradation by Pseudomonas putida CA-3. Appl Environ Microbiol 61, 544-548.

O'Connor, K. E., Duetz, W., Wind, B. \& Dobson, A. D. W. (1996). The effect of nutrient limitation on styrene metabolism in Pseudomonas putida CA-3. Appl Environ Microbiol 62, 3594-3599.

O'Connor, K. E., Witholt, B. \& Duetz, W. (2001). p-Hydroxyphenylacetic acid metabolism in Pseudomonas putida F6. J Bacteriol 183, 928-933.

O'Leary, N. D., O'Connor, K. E., Duetz, W. \& Dobson, A. D. W. (2001). Transcriptional regulation of styrene degradation in Pseudomonas putida CA-3. Microbiology 147, 973-979.

O'Leary, N. D., Duetz, W. A., Dobson, A. D. \& O'Connor, K. E. (2002a). Induction and repression of the sty operon in Pseudomonas putida CA-3 during growth on phenylacetic acid under organic and inorganic nutrient-limiting continuous culture conditions. FEMS Microbiol Lett 208, 263-268.

O'Leary, N. D., O'Connor, K. E. \& Dobson, A. D. W. (2002b). Biochemistry, genetics and physiology of microbial styrene degradation. FEMS Microbiol Rev 26, 403-417.

O'Leary, N. D., O'Connor, K. E., Ward, P., Goff, M. \& Dobson, A. D. W. (2005). Genetic characterization of accumulation of polyhydroxyalkanoate from styrene in Pseudomonas putida CA-3. Appl Environ Microbiol 71, 4380-4387. 
Olivera, E. R., Minambres, B., Garcia, B., Muntiz, C., Moreno, M. A., Ferrandez, A., Diaz, E., Garcia, J. L. \& Luengo, J. M. (1998). Molecular characterization of the phenylacetic acid catabolic pathway in Pseudomonas putida U: the phenylacetyl-CoA catabolon. Proc Natl Acad Sci U S A 95, 6419-6424.

O'Toole, G. A. \& Kolter, R. (1998). Initiation of biofilm formation in Pseudomonas fluorescens WCS365 proceeds via multiple, convergent signalling pathways: a genetic analysis. Mol Microbiol 28, 449-461.

Park, S. J. \& Lee, S. Y. (2005). Systems biological approach for the production of various polyhydroxyalkanoates by metabolically engineered Escherichia coli. Macromol Symp 224, 1-10.

Park, J. H., Lee, S. Y., Kim, T. Y. \& Kim, H. U. (2008). Application of systems biology for bioprocess development. Trends Biotechnol 26, 404-412.

Patel, C. N., Wortham, B. W., Lines, J. L., Fetherston, J. D., Perry, R. D. \& Oliveira, M. A. (2006). Polyamines are essential for the formation of plague biofilm. J Bacteriol 188, 2355-2363.

Patrauchan, M. A., Sarkisova, S. A. \& Franklin, M. J. (2007). Strainspecific proteome responses of Pseudomonas aeruginosa to biofilmassociated growth and to calcium. Microbiology 153, 3838-3851.

Pötter, M. \& Steinbüchel, A. (2005). Poly(3-hydroxybutyrate) granule-associated proteins: impacts on poly(3-hydroxybutyrate) synthesis and degradation. Biomacromolecules 6, 552-560.

Pötter, M., Muller, H., Reinecke, F., Wieczorek, R., Fricke, F., Bowien, B., Friedrich, B. \& Steinbüchel, A. (2004). The complex structure of polyhydroxybutyrate (PHB) granules: four orthologous and paralogous phasins occur in Ralstonia eutropha. Microbiology 150, 2301-2311.

Raberg, M., Reinecke, F., Reichelt, R., Malkus, U., König, S., Pötter, M., Fricke, W. F., Pohlmann, A., Voigt, B. \& other authors (2008). Ralstonia eutropha H16 flagellation changes according to nutrient supply and state of poly(3-hydroxybutyrate) accumulation. Appl Environ Microbiol 74, 4477-4490.

Raghava, G. P. S. (2006). MANGO: prediction of Genome Ontology (GO) class of a protein from its amino acid and dipeptide composition using nearest neighbor approach. CASP7 93.

Ramos, J. L., Gallegos, M.-T., Marqués, S., Ramos-González, M.-I., Espinosa-Urgel, M. \& Segura, A. (2001). Responses of Gram-negative bacteria to certain environmental stressors. Curr Opin Microbiol 4, 166-171.

Ramos, J. L., Duque, E., Gallegos, M.-T., Godoy, P., RamosGonzález, M. I., Rojas, A., Terán, W. \& Segura, A. (2002). Mechanisms of solvent tolerance in Gram-negative bacteria. Annu Rev Microbiol 56, 743-768.

Ramos-Gonzalez, M.-I., Ruiz-Cabello, F., Brettrar, I., Garrido, F. \& Ramos, J. L. (1992). Tracking genetically engineered bacteria: monoclonal antibodies against surface determinants of the soil bacterium Pseudomonas putida 2440. J Bacteriol 174, 2978-2985.

Rehm, B. H. (2007). Biogenesis of microbial polyhydroxyalkanoate granules: a platform technology for the production of tailor-made bioparticles. Curr Issues Mol Biol 9, 41-62.

Sandoval, A., Arias-Barrau, E., Arcos, M., Naharro, G., Olivera, E. R. \& Luengo, J. M. (2007). Genetic and ultrastructural analysis of different mutants of Pseudomonas putida affected in the poly-3-hydroxy-nalkanoate gene cluster. Environ Microbiol 9, 737-751.

Santos, P. M., Benndorf, D. \& Sa-Correia, I. (2004). Insights into Pseudomonas putida KT2440 response to phenol-induced stress by quantitative proteomics. Proteomics 4, 2640-2652.

Santos, P. M., Roma, V., Benndorf, D., von Bergen, M., Harms, H. \& Sa-Correia, I. (2007). Mechanistic insights into the global response to phenol in the phenol-biodegrading strain Pseudomonas sp. M1 revealed by quantitative proteomics. OMICS 11, 233-251.
Scheiner, D. (1976). Determination of ammonia and Kjeldahl nitrogen by indophenol method. Water Res 10, 31-36.

Schlegel, H. G., Kaltwasser, H. \& Gottschalk, G. (1961). A submersion method for culture of hydrogen-oxidizing bacteria: growth physiological studies. Arch Mikrobiol 38, 209-222 in German.

Shevchenko, A., Wilm, M., Vorm, O. \& Mann, M. (1996). Mass spectrometric sequencing of proteins silver-stained polyacrylamide gels. Anal Chem 68, 850-858.

Smith, J. L. (2004). The physiological role of ferritin-like compounds in bacteria. Crit Rev Microbiol 30, 173-185.

Sobolevsky, T. G., Revelsky, A. I., Revelsky, I. A., Miller, B. \& Oriedo, V. (2004). Simultaneous determination of fatty, dicarboxylic and amino acids based on derivatization with isobutyl chloroformate followed by gas chromatography-positive ion chemical ionization mass spectrometry. J Chromatogr B Analyt Technol Biomed Life Sci 800, 101-107.

Squires, C. \& Squires, C. L. (1992). The Clp proteins: proteolysis regulators or molecular chaperones? J Bacteriol 174, 1081-1085.

Taylor, M., Tuffin, M., Burton, S., Eley, K. \& Cowan, D. (2008). Microbial responses to solvent and alcohol stress. Biotechnol $J$ 3, $1388-1397$.

Tessmer, N., Konig, S., Malkus, U., Reichelt, R., Pötter, M. \& Steinbuchel, A. (2007). Heat-shock protein HspA mimics the function of phasins sensu stricto in recombinant strains of Escherichia coli accumulating polythioesters or polyhydroxyalkanoates. Microbiology 153, 366-374.

Velasco, A., Alonso, S., Garcia, J. L., Perera, J. \& Diaz, E. (1998). Genetic and functional analysis of the styrene catabolic cluster of Pseudomonas sp. strain Y2. J Bacteriol 180, 1063-1071.

VerBerkmoes, N. C., Shah, M. B., Lankford, P. K., Pelletier, D. A., Strader, M. B., Tabb, D. L., McDonald, W. H., Barton, J. W., Hurst, G. B. \& other authors (2006). Determination and comparison of the baseline proteomes of the versatile microbe Rhodopseudomonas palustris under its major metabolic states. J Proteome Res 5, 287-298.

Volker, U., Engelmann, S., Maul, B., Roethdorf, S., Voelker, A. \& Schmid, R. (1994). Analysis of the induction of stress proteins of Bacillus subtilis. Microbiology 140, 741-752.

Volkers, R. J. M., de Jong, A. L., Hulst, A. G., van Baar, B. L. M., de Bont, J. A. M. \& Wery, J. (2006). Chemostat-based proteomic analysis of toluene-affected Pseudomonas putida S12. Environ Microbiol 8, 1674-1679.

von Wallbrunn, A., Richnow, H. H., Neumann, G., Meinhardt, F. \& Heipieper, H. J. (2003). Mechanism of cis-trans isomerization of unsaturated fatty acids in Pseudomonas putida. J Bacteriol 185, 17301733.

Wältermann, M. \& Steinbüchel, A. (2005). Neutral lipid bodies in prokaryotes: recent insights into structure, formation, and relationship to eukaryotic lipid depots. J Bacteriol 187, 3607-3619.

Ward, P. G. \& O'Connor, K. E. (2005). Induction and quantification of phenylacyl-CoA ligase enzyme activities in Pseudomonas putida CA-3 grown on aromatic carboxylic acids. FEMS Microbiol Lett 251, 227232.

Ward, P. G., de Roo, G. \& O'Connor, K. E. (2005). Accumulation of polyhydroxyalkanoate from styrene and phenylacetic acid by Pseudomonas putida CA-3. Appl Environ Microbiol 71, 2046-2052.

Ward, P. G., Goff, M., Donner, M., Kaminsky, W. \& O'Connor, K. E. (2006). A two step chemo-biotechnological conversion of polystyrene to a biodegradable thermoplastic. Environ Sci Technol 40, 2433-2437.

Washburn, M. P., Ulaszek, R. R. \& Yates, J. R. I. (2003). Reproducibility of quantitative proteomic analyses of complex 
biological mixtures by multi-dimensional protein identification technology. Anal Chem 75, 5054-5061.

Welinder, K. G. (1991). Bacterial catalase-peroxidases are gene duplicated members of the plant peroxidase superfamily. Biochim Biophys Acta 1080, 215-220.
Whang, L.-M., Liu, P.-W. G., Ma, C.-C. \& Cheng, S.-S. (2008). Application of biosurfactants, rhamnolipid, and surfactin, for enhanced biodegradation of diesel-contaminated water and soil. J Hazard Mater 151, 155-163.

Edited by: M. A. Kertesz 